\title{
Lack of Annexin A6 Exacerbates Liver Dysfunction and Reduces Lifespan of Niemann-Pick Type C Protein-Deficient Mice
}

Elsa Meneses-Salas, ${ }^{* \dagger}$ Marta Garcia-Forn, ${ }^{\dagger \S}$ Carla Castany-Pladevall, ${ }^{\ddagger \S}$ Albert Lu, ${ }^{\dagger \uparrow}$ Alba Fajardo, ${ }^{\dagger}$ Jaimy Jose, Mohamed Wahba, Marta Bosch,,$^{* \dagger}$ Albert Pol, ${ }^{* \dagger * *}$ Francesc Tebar, ${ }^{* \dagger}$ Andrés D. Klein, ${ }^{\dagger \dagger}$ Silvana Zanlungo, ${ }^{+\dagger}$ Esther Pérez-Navarro, ${ }^{\ddagger}$ Thomas Grewal, $\|$ Carlos Enrich, ${ }^{* \dagger}$ and Carles Rentero ${ }^{* \dagger}$

\begin{abstract}
From the Unitat de Biologia Cel-lular* and Institut de Neurociències, ${ }^{\ddagger}$ Departament de Biomedicina, Facultat de Medicina i Ciències de la Salut, Universitat de Barcelona, Barcelona, Spain; the Centre de Recerca Biomèdica CELLEX $X^{\dagger}$ and Centro de Investigación Biomédica en Red sobre Enfermedades Neurodegenerativas (CIBERNED), ${ }^{\S}$ Institut d'Investigacions Biomèdiques August Pi i Sunyer (IDIBAPS), Barcelona, Spain; the Department of Biochemistry, Stanford University School of Medicine, Stanford, California; the School of Pharmacy," Faculty of Medicine and Health, University of Sydney, Sydney, New South Wales, Australia; the Institució Catalana de Recerca i Estudis Avançats (ICREA);** the Centro de Genética y Genómica, ${ }^{\dagger \dagger}$ Universidad del Desarrollo, Clínica Alemana de Santiago, Chile; and the Departamento de Gastroenterología, ${ }^{\ddagger \ddagger}$ Facultad de Medicina Pontificia Universidad Católica de Chile, Santiago, Chile
\end{abstract}

\author{
Accepted for publication \\ December 9, 2020. \\ Address correspondence to \\ Carles Rentero, Ph.D. or Carlos \\ Enrich, Ph.D., Departament de \\ Biomedicina, Unitat de Bio- \\ logia Cel-lular, Facultat de \\ Medicina i Ciències de la Salut, \\ Universitat de Barcelona and \\ Centre de Recerca Biomèdica \\ CELLEX, Institut d'Investiga- \\ cions Biomèdiques August Pi i \\ Sunyer (IDIBAPS), Carrer \\ Casanova, 143, Barcelona \\ 08036, Spain. E-mail: carles. \\ rentero@ub.edu or enrich@ub. \\ edu.
}

\begin{abstract}
Niemann-Pick type C (NPC) disease is a lysosomal storage disorder characterized by cholesterol accumulation caused by loss-of-function mutations in the Npc1 gene. NPC disease primarily affects the brain, causing neuronal damage and affecting motor coordination. In addition, considerable liver malfunction in NPC disease is common. Recently, we found that the depletion of annexin A6 (ANXA6), which is most abundant in the liver and involved in cholesterol transport, ameliorated cholesterol accumulation in Npc1 mutant cells. To evaluate the potential contribution of ANXA6 in the progression of NPC disease, double-knockout mice $\left(\mathrm{NpC1}^{-/-} / \mathrm{Anxa}^{-/-}\right)$were generated and examined for lifespan, neurologic and hepatic functions, as well as liver histology and ultrastructure. Interestingly, lack of ANXA6 in NPC1-deficient animals did not prevent the cerebellar degeneration phenotype, but further deteriorated their compromised hepatic functions and reduced their lifespan. Moreover, livers of $\mathrm{NpC1}^{-/-} / \mathrm{Anxa6}^{-/-}$mice contained a significantly elevated number of foam cells congesting the sinusoidal space, a feature commonly associated with inflammation. We hypothesize that ANXA6 deficiency in $\mathrm{NpC1}^{-/-}$mice not only does not reverse neurologic and motor dysfunction, but further worsens overall liver function, exacerbating hepatic failure in NPC disease. (Am J Pathol 2021, 191: 475-486; https://doi.org/10.1016/j.ajpath.2020.12.009)
\end{abstract}

Niemann-Pick type C (NPC) disease is an autosomal-recessive disorder characterized by cholesterol accumulation in endolysosomes of the liver, spleen, and central nervous system (CNS), with the CNS accumulation causing fatal progressive neurodegeneration. NPC disease is mainly caused by loss-of-function mutations in the $\mathrm{Npcl}(95 \%)$ gene, which encodes the major cholesterol transporter in endolysosomes. ${ }^{1}$ NPC1 deficiency blocks the exit of cholesterol from endolysosomes, eliciting cellular and organ dysfunction. ${ }^{2,3}$ Mice with mutations in the $N p c l$ gene have been widely used to study the underlying mechanisms that cause this disease. ${ }^{4}$

\footnotetext{
Supported by Ministerio de Economía y Competitividad and ConsoliderIngenio grants BFU2015-66785-P, CSD2009-00016, and BFU2016-81912REDC (C.E.), SAF2016-08573-R (E.P.-N.), and RTI2018-098593-B-I00 (A.P.) the CONICYT Research Program (2018 to 2020) (S.Z.); the International Mobility Program, Universitat de Barcelona (2018) (C.E.); University of Sydney grants RY253 and U3367 (T.G.); and the Serra Húnter Program (Generalitat de Catalunya) (C.R.).

E.M.-S. and M.G.-F. contributed equally to this work.

Disclosures: None declared.

Current address of E.M.-S., Department of Molecular Medicine, Scripps Research, La Jolla, CA; of M.G.-F., Seaver Autism Center for Research and Treatment, Icahn School of Medicine at Mount Sinai, New York, NY.
} 
In the brain and CNS of patients with NPC disease as well as NPC1-deficient mice, the endolysosomal accumulation of cholesterol and other lipids greatly contribute to pathologic changes and neurodegeneration such as a marked loss of cerebellar Purkinje cells, impairing motor tasks. ${ }^{5}$ In the liver, NPC1 deficiency also causes cholesterol accumulation, which then activates nonparenchymal cells, including Kupffer and hepatic stellate cells, leading to progressive inflammation, oxidative stress, apoptosis, and fibrosis. $^{6-13}$ This process correlates with large number of CD68-positive Kupffer cells in $\mathrm{Npcl}^{-/-}$mouse livers, ${ }^{14}$ and some findings suggest that lipid accumulation of Kupffer cells could induce secretion of inflammatory cytokines, such as tumor necrosis factor and profibrotic transforming growth factor $\beta$.

The liver is mainly composed of parenchymal hepatocytes (approximately 60\% to $70 \%$ ) and nonparenchymal endothelial, Kupffer, and stellate cells. In addition, cells of the biliary track, natural killer cells, as well as adaptive Tand B-lymphocytes can also be found in the liver. ${ }^{15}$ Kupffer cells, which constitute $80 \%$ to $90 \%$ of the resident tissue macrophages, have zonal distribution associated with differences in their size, phagocytic activity, cytokine production, cytotoxic capacity, and lysosomal enzyme activities. ${ }^{16,17}$ However, cholesterol accumulation in NPC disease impairs the proper functioning of its endolysosomes, possibly also compromising Kupffer cell behavior. ${ }^{18}$

Interestingly, we previously found that restoration of hepatic NPC1 expression in $\mathrm{Npcl}^{-/-}$mice reduced hepatomegaly and hepatic cholesterol level, as well as bile salts, bilirubin, and transaminase levels in serum, without ameliorating the onset or progression of neurodegeneration. ${ }^{19,20}$ In addition, several other endolysosomal proteins in the vicinity of NPC1 appear to influence NPC1dependent activities and may contribute to the complex NPC pathology. ${ }^{21-23}$

Annexin A6 (ANXA6) belongs to the family of annexins $^{24}$ and is expressed in most tissues, being highly abundant in the liver ${ }^{25}$ and brain. ${ }^{26}$ In the liver, ANXA6 as a marker for hepatocytic endosomes ${ }^{27}$ is preferentially localized in a subset of pericanalicular (apical) endosomes. ${ }^{28-30}$ Interestingly, multiple ANXA6 interactions likely relevant for proper hepatic functioning are often linked to NPC1, such as autophagocytosis, cholesterol homeostasis, lysosomal function, or gluconeogenesis. ${ }^{30,31}$ Indeed, upregulated ANXA6 levels contributed to the compromised cholesterol transport in NPC1-deficient cells ${ }^{21}$ and cholesterol-sensitive lysosomal degradation, ${ }^{18}$ whereas hepatic ANXA6 deficiency hindered glucose homeostasis and survival during liver regeneration. ${ }^{31}$

In this study, analysis of double-knockout mice lacking NPC1 and ANXA6 $\left(\mathrm{Npcl}^{-/-} / \mathrm{Anxa}^{-/-}\right)$revealed a significant reduction of lifespan compared with $\mathrm{Npcl}^{-1-}$ mice, which correlated with a slight amelioration of some neurologic functions but overall worsening in motor coordination abilities. In addition, loss of ANXA6 in NPC1-deficient animals decreased hepatic cholesterol esters (CEs) without modifying unesterified cholesterol (UC) levels, deteriorated hepatic function, and markedly increased the number of foam cells in the liver, indicating increased liver inflammation. In conclusion, ANXA6 depletion is highly detrimental for the hepatic physiologic processes of NPCdeficient mice.

\section{Materials and Methods}

\section{Animals}

Two genetic crosses using homozygous Anxa6 $6^{-/-32}$ and heterozygous $\mathrm{Npcl}^{+/-19}$ mice on the C57BL/6 genetic background ( $99 \%$ pure) were performed to generate parental $\mathrm{Npcl}^{+/-} / \mathrm{Anxa6}^{-/-}$mice. After two additional crosses, the F2 generation of wild-type (WT), Anxa6 ${ }^{-1-}, \mathrm{Npcl}^{-/-}$, and $\mathrm{Npcl}^{-1-} / \mathrm{Anxa6}^{-1-}$ animals was analyzed. Mice were maintained in a 12-hour light/dark cycle and allowed food and water ad libitum. With regard to diet, mice were fed with regular low-cholesterol, low-fat cereal-based rodent chow diet (2014 Teklad Global 14\% protein rodent maintenance diet; Envigo, Indianapolis, IN).

\section{Genotype Analysis}

Genomic DNA extraction and PCR genotyping were performed using the Accustart II Mouse Genotyping Kit (Quanta BioScience Inc., Gaithersburg, MD). The Npcl knockout alleles were detected as described previously. ${ }^{19}$ The Anxa6 knockout alleles were detected using Anxa6 primers (forward 5'-GAGGCTCTGTCCACGACTT-3' and reverse $5^{\prime}$-CCAATAAAGTCACTGGTTCATC-3') and a primer for the Neomycin resistance gene cassette $\left(5^{\prime}\right.$ TCTGGACGAAGAGCATCA-3'), resulting in a 250 -bp product for the WT Anxa6 allele and a 500-bp product for the Anxa6 knockout allele.

\section{Morphologic Analysis}

Eight-week-old mice were euthanized by decapitation. Immediately after, the livers and brains were removed and processed for histology and protein and RNA extraction as previously described. ${ }^{31,33}$ Briefly, liver and brain tissues were fixed in $4 \%$ paraformaldehyde (Electron Microscopy Sciences, Hatfield, PA) in $0.1 \mathrm{~mol} / \mathrm{L}$ sodium phosphate $\mathrm{pH}$ 7.2 for 96 hours. After fixation, liver tissues were paraffinembedded, sectioned $(12 \mu \mathrm{m})$, and stained with hematoxylin and eosin (H\&E) or Masson's trichrome stain. Brain tissues were cryoprotected with $30 \%$ sucrose in phosphatebuffered saline with $0.02 \%$ sodium azide and frozen in dryice-cooled 2-methylbutane. Serial sagittal sections $(30-\mu \mathrm{m}$ thick) were cut on a cryostat and collected as free-floating sections. Some were stained with Cresyl violet (Nissl staining) as previously described, ${ }^{34}$ others were stained with filipin $\left(125 \mu \mathrm{g} / \mathrm{mL}\right.$ for 3 hours), ${ }^{35}$ and yet others were 
processed for immunohistochemistry. For nuclei staining, TO-PRO-3 (Invitrogen, Carlsbad, CA) was used. Antiionized calcium-binding adaptor molecule 1 (IBA1; Wako, Richmond, VA) and anti-glial fibrillary acidic protein (GFAP; Dako North America Inc., Carpinteria, CA) antibodies were used for free-floating immunofluorescence as previously described. ${ }^{36}$ Anti-calbindin D-28k was used for the detection of Purkinje cells in the cerebellum. Sections were incubated with biotinylated secondary antibodies (Swant, Marly, Switzerland) and developed with diaminobenzidine, as previously described. ${ }^{33}$ Calbindin staining was analyzed in eight slices per animal separated by 240 $\mu \mathrm{m}$ using a magnification of $\times 10$ with an Olympus BX50 fluorescence microscope coupled with an Olympus XC30 camera (Olympus, Tokyo, Japan). Filipin-stained samples were visualized using a Zeiss LSM880 laser scanning confocal microscope (Carl Zeiss Microscopy GmbH, Jena, Germany). The quantification of Purkinje cells was performed using ImageJ software version 1.51 (NIH, Bethesda, MD; https://imagej.nih.gov/ij) ${ }^{37}$ as previously described. ${ }^{38}$

\section{Biochemical Analysis and Western Blotting}

Blood was collected by intracardiac puncture into BD Microtainer tubes (Becton Dickinson Co., Franklin Lakes, $\mathrm{NJ}$ ). Serum was collected after centrifugation of blood samples at $6000 \times g$ for 1 minute at $4^{\circ} \mathrm{C}$ in Serum Heparin Separator Tubes (Becton Dickinson). Serum parameters were determined by the core facility of Hospital Clínic i Provincial de Barcelona as previously described ${ }^{31}$ for at least five mice for each parameter. UC and CEs were determined using the Amplex Red Cholesterol Assay kit (Molecular Probes, Eugene, OR) according to the manufacturer's instructions. Western blotting was performed using rabbit anti-NPC1 (Abcam, Cambridge, UK), rabbit anti-ANXA6, goat anti-glyceraldehyde-3-phosphate dehydrogenase (GAPDH; Genescript, Piscataway, NJ), rabbit anti-calbindin D-28K (Swant), mouse anti- $\alpha$-tubulin (Sigma-Aldrich, St Louis, MO), mouse anti-GAPDH (Millipore Corp, Burlington, MA), rabbit anti-GFAP (Dako), and rabbit anti-IBA1 (Wako). The intensity of calbindin, IBA1, and GFAP signals was quantified using Gelpro32 version 4.0.0.4 (Media Cybernetics Inc., Rockville, MD), and results were normalized to $\alpha$-tubulin or GAPDH.

\section{Quantitative PCR}

Total RNA was extracted using QIAzol lysis reagent and RNeasy Lipid Tissue Mini kit (Qiagen, Hilden, Germany) in accordance with the manufacturer's protocol. A total of $1 \mu \mathrm{g}$ of RNA was reversed transcribed using a High Capacity cDNA Reverse Transcription Kit (Applied Biosystems, Foster City, CA). In a final volume of $20 \mu \mathrm{L}$ of real-time PCR Brilliant SYBRGreen QPCR Master Mix (Stratagene,
San Diego, CA), $2 \mu \mathrm{L}$ of 1:20 diluted cDNA, specific primers (Illb forward 5'-TGCCACCTTTTGACAGTGATG- $3^{\prime}$ and reverse $5^{\prime}$-AAGGTCCACGGGAAAGACAC-3'; Tnf forward 5'-GTCCCCAA AGGGATGAGAAGT- $3^{\prime}$ and reverse 5'-ACAAGGTACAACCCATCGGC-3'; Il6 forward 5'-TCCTCTCTG CAAGAGACTTCC- $3^{\prime}$ and reverse 5'-CTGCAAGTGCATCATCGTTGT-3'; Tbp forward 5'-CACCCCTTGTACCCTTCAC- $3^{\prime}$ and reverse 5'-TTCACTCTTG GCTCCTGTGC- $3^{\prime}$ ), and standard PCR amplification protocol $\left(10\right.$ minutes at $95^{\circ} \mathrm{C} ; 45$ cycles of 30 seconds at $95^{\circ} \mathrm{C}$, 15 seconds at $60^{\circ} \mathrm{C}$, and 30 seconds at $72^{\circ} \mathrm{C}$; and 10 seconds at $95^{\circ} \mathrm{C}$ and 60 seconds at $65^{\circ} \mathrm{C}$ ) were used for PCR analysis using the LightCycler system (Roche Diagnostics, Hoffmann-La Roche, Basel, Switzerland). Values were normalized to the mouse Tbp mRNA in each sample. ${ }^{39}$

\section{Electron Microscopy}

For electron transmission microscopy, livers were taken from mice after administration of anesthesia after intracardial perfusion with $2.5 \%$ glutaraldehyde in phosphate buffer. Liver samples were then fixed overnight in $2.5 \%$ glutaraldehyde and 4\% paraformaldehyde and postfixed in osmium tetroxide and embedded in Spurr (Sigma-Aldrich). Images were acquired from ultrathin sections using a JEOL1010 electron microscope (JEOL USA Inc., Peabody, MA) with a SC1000 ORIUS-CCD digital camera (Gatan Inc., Pleasanton, CA).

\section{Behavioral Assessment}

Sensory capabilities of mice were evaluated by using the SHIRPA (SmithKline Beecham, Harwell, Imperial College, Royal London Hospital phenotype assessment) standard task battery, and muscular strength and motor coordination were examined by the wire hanger test previously described. ${ }^{40,41}$ Motor behavior was further analyzed using the footprint test, the open field test, and the balance beam test. ${ }^{42,43}$

\section{Statistical Analysis}

Data are expressed as the means \pm SEM. Statistical analysis of mouse survival was performed with a log-rank (MantelCox) test, and analysis of interaction was performed with a two-way analysis of variance with ad hoc Bonferroni posttest. Statistical comparison of four groups was performed using one-way analysis of variance with ad hoc Sidak posttest. Statistical analysis was performed in GraphPad Prism software version 8 (GraphPad Software, San Diego, CA). 


\section{Results}

Characterization of $\mathrm{Npc1}^{-/-} / \mathrm{Anxa6^{-/- }}$ Mice

To determine the contribution of ANXA6 in the neuronal and hepatic dysfunction associated with NPC disease, $\mathrm{Npcl}^{-1-} / \mathrm{Anxa}^{-/-}$double-knockout mice were generated. PCR genotyping (not shown) and Western blotting (Figure 1A) confirmed the identity of genotypes generated ( $\geq 14$ mice per genotype). We initially assessed the lifespan of each strain. Similar to previous studies, the lifespan of Anxa $6^{-/-}$animals was not affected,,$^{31,32}$ but was reduced for $\mathrm{NpCl}^{-1-}$ mice to a mean of 69 days ${ }^{19}$ compared with controls ( $>1$ year). However, ANXA6 deficiency further compromised the lifespan of $\mathrm{Npcl}^{-/-}$mice because survival of $\mathrm{Npcl}^{-1-} / \mathrm{Anxa}^{-1-}$ mice was significantly reduced to a mean of 62 days (Figure 1B). In addition, both WT and Anxa6 $6^{-1-}$ animals had a gradual weight increase during a 2to 12 -week period. Both $\mathrm{Npcl}^{-/-}$and $\mathrm{Npcl}^{-1-} / \mathrm{Anxa6}^{-1-}$ animals had a slightly reduced body weight compared with that for controls, which gradually increased until week 7 and decreased thereafter (Figure 1C). When sex differences were analyzed with reference to lifespan and weight, no statistical differences were detected for all four strains (data not shown).

Given that ANXA6 depletion can ameliorate cholesterol accumulation in $\mathrm{Npcl}$ mutant cells, ${ }^{21}$ we aimed to determine whether loss of ANXA6 improved aspects of the neurologic and motor phenotype of $\mathrm{Npcl}^{-/-}$mice., ${ }^{9,44-46}$ Overall sensory and physical condition was initially assessed using the SHIRPA standardized battery test and the wire hanger test. SHIRPA analysis revealed a partial amelioration of the sensory capabilities in $\mathrm{Npcl}^{-1-} / \mathrm{Anxa6^{-1 }}$ compared with those in $\mathrm{Npcl}^{-/-}$mice, which presented a significant decrease in the SHIRPA score compared with WT mice (Figure 2A). In addition, loss of ANXA6 partially improved muscular strength in $\mathrm{Npcl}^{-1-}$ mice (Figure 2B). However,
$\mathrm{Npcl}^{-1-} \mid \mathrm{Anxa6^{-/- }}$ mice moved significantly less in the wire hanger than did the controls (Figure 2C), and both $\mathrm{Npcl}^{-/-}$and $\mathrm{Npcl}^{-1-} / \mathrm{Anxa6^{-/ }}$ mice used a smaller number of limbs to stay up in the hanger (Figure 2D). Altogether, these results suggest an underlying alteration in motor coordination. The balance beam test was used to assess whether ANXA6 deficiency affected motor coordination in $\mathrm{Npcl}^{-/-}$mice. As previously described, ${ }^{47}$ $\mathrm{NpCl}^{-1-}$ mice presented an alteration in motor coordination in both wooden and iron rods compared with controls (Figure 2, E-H). ANXA6 deletion in $\mathrm{Npcl}^{-/-}$mice did not improve their motor capacities (Figure 2, E-H). In fact, $\mathrm{NpCl}^{-/-} / \mathrm{Anxa6}^{-/-}$mice moved significantly less than $\mathrm{NpCl}^{-1-}$ mice in a more motor-demanding context (Figure 2G), suggesting a worsening of the $\mathrm{NpCl}^{-/-}$phenotype with loss of ANXA6. We further analyzed motor behavior in the open field. No differences were found regarding anxiety among control, $\mathrm{Npcl}^{-/}$, and $\mathrm{Npcl}^{-/-} / \mathrm{Anxa6}^{-1-}$ mice (Supplemental Figure S1, A and B). Interestingly, ANXA6 deficiency improved the stereotypic phenotype in $\mathrm{Npcl}^{-/-}$mice (Figure 2I). In line with the results in the balance beam test, not only $\mathrm{Npcl}^{-/}$but also $\mathrm{Npcl}^{-/-} / \mathrm{Anxa}^{-/-}$mice stood up less and for shorter times in the open field without the help of the wall (Figure 2, $\mathrm{J}$ and $\mathrm{K}$ ), a very motor coordination-demanding phenotype. However, no differences compared with WT mice were observed in the rearing behavior when using the wall as a support or in the distance traveled (Supplemental Figure S1, $\mathrm{C}-\mathrm{E})$. Finally, $\mathrm{NpcI}^{-/-} / \mathrm{Anxa6^{-/- }}$ mice fell off significantly more than controls after standing up (Figure 2L). Overall, these results indicate that ANXA6 deficiency does not improve, but rather worsens, some parameters of the motor phenotype in $\mathrm{Npcl}^{-/-}$mice.

Cerebellar Purkinje cell loss is a hallmark of cerebellar neurodegeneration in patients with NPC disease and $\mathrm{Npcl}$ knockout mouse models that contributes to compromised motor coordination. ${ }^{48}$ Even though no gross cerebellar
A

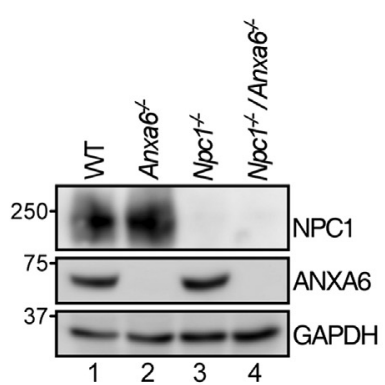

B

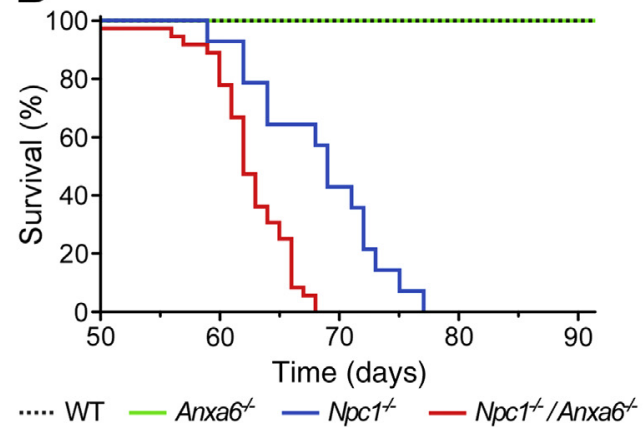

C

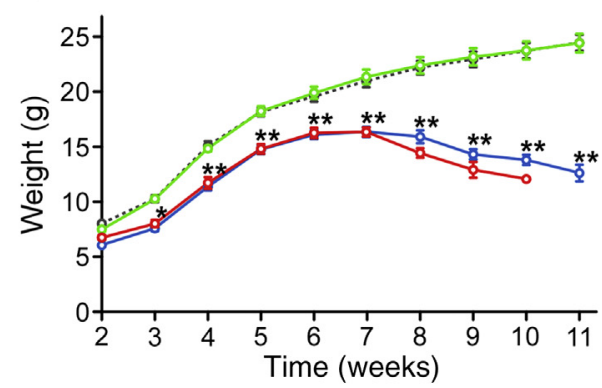

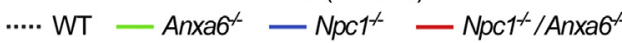

Figure 1 Survival and body weight of $\mathrm{Npc1}^{-/-} / \mathrm{Anxa6}^{-/-}$mice. A: Western blot analysis of Niemann-Pick type C 1 (NPC1) and annexin A6 (ANXA6) protein

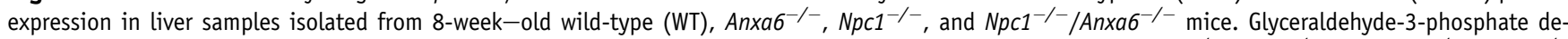

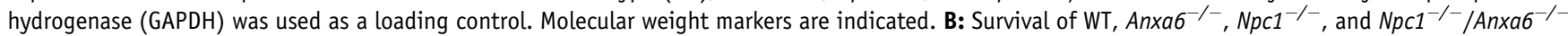
mice. The lifespan (\%) in days is given. Nonstatistically significance sex differences were observed (not shown). C: Body weight in WT, Anxa6 ${ }^{-/-}$, Npc1 ${ }^{-/-}$, and $\mathrm{NpC1}^{-/-} / \mathrm{Anxa6}^{-/-}$mice during a 2- to 11 -week period. $n=14$ to 36 per genotype (B); $n=22$ to 31 per genotype $(\mathbf{C}) .{ }^{*} P<0.01,{ }^{* *} P<0.001 \mathrm{Npc1}{ }^{-/-}$ and $\mathrm{NpC1}^{-/-} / \mathrm{Anxa6}^{-1-}$ mice versus WT and $\mathrm{Anxa6^{-/- }}$ mice. 

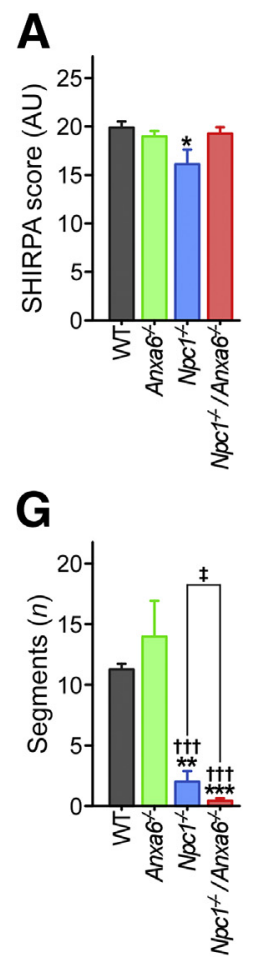

B

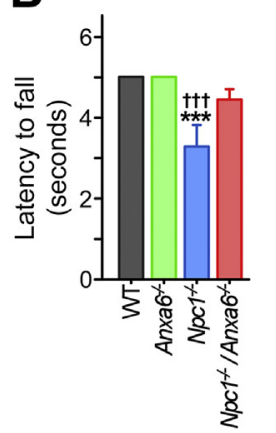

H

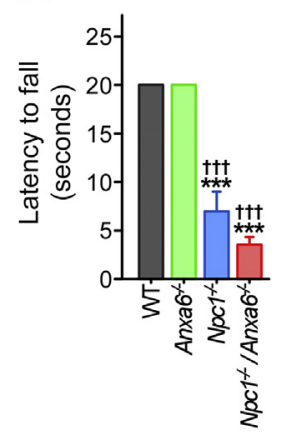

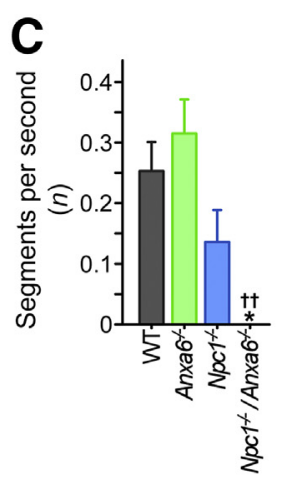

I

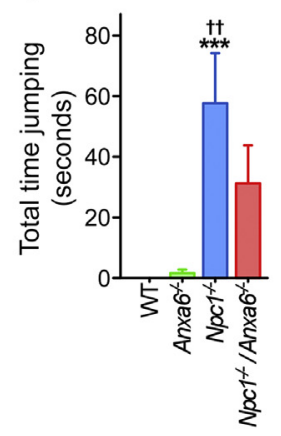

D

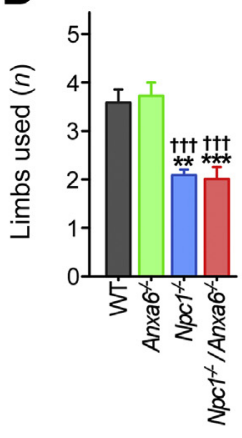

J

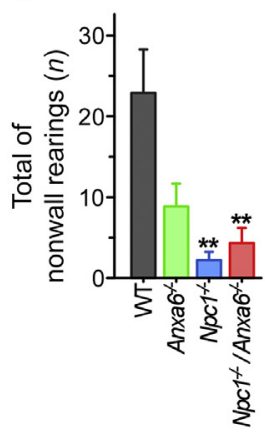

E

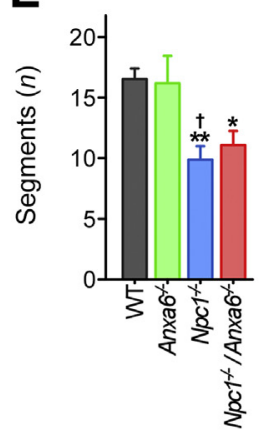

K

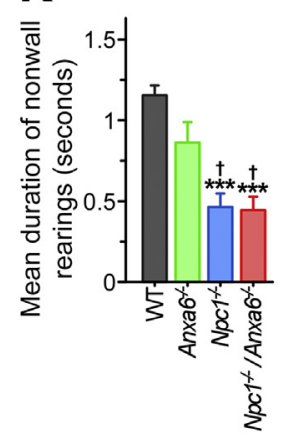

F

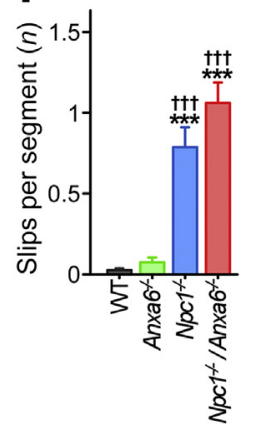

L

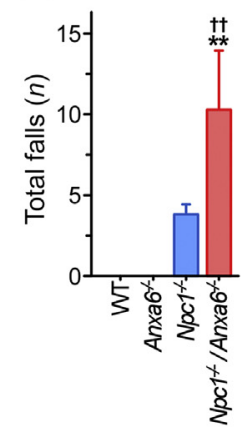

Figure 2 Behavioral and cerebellar evaluation of 8-week-old $\mathrm{Npc1}^{-/-} / \mathrm{Anxa6^{-/ }}$ mice. Behavior was assessed using SHIRPA (SmithKline Beecham, Harwell, Imperial College, Royal London Hospital phenotype assessment) (A), wire hanger test (B-D), wooden balance beam (E-F), iron balance beam (G-H), and open field (I-L). Data are expressed as means \pm SEM. $n=5$ to 10 per genotype. ${ }^{*} P<0.05,{ }^{* *} P<0.01$, and ${ }^{* * *} P<0.001$ versus wild-type (WT) mice; ${ }^{\dagger} P<0.05,{ }^{\dagger \dagger} P<0.01$, and ${ }^{\dagger \dagger} P<0.001$ versus $A n x a 6^{-/-}$mice; ${ }^{\ddagger} P<0.05$.

histologic abnormalities were observed using Nissl staining (Supplemental Figure S1F), we found an equal loss of Purkinje cells in the cerebellum of $\mathrm{Npcl}^{-1-}$ and $\mathrm{Npcl}^{-1-}$ Anxa6 ${ }^{-1-}$ mice compared with controls, as indicated by calbindin staining and protein levels (Figure 3, A and B). In addition, protein levels, as well as the number of IBA1- and GFAP-positive cells (microglia and astrocytes, respectively) were similarly increased in the cerebellum of 8-week-old $\mathrm{NpCl}^{-/-}$and $\mathrm{Npcl}^{-/-} / \mathrm{Anxa}^{-/-}$mice compared with WT or Anxa6 ${ }^{-1-}$ animals (Supplemental Figure S2, A-C). Moreover, filipin staining confirmed an accumulation of UC mainly in the remaining Purkinje cells of $\mathrm{Npcl}^{-1-}$ and $\mathrm{NpCl}^{-/-} / \mathrm{Anxa6}^{-/-}$mice (Figure 3C). Altogether, these results suggest that the slight worsening in motor coordination and the decreased lifespan in $N p c 1^{-1-} / A n x a 6^{-1-}$ mice were not consequences of increased cerebellar degeneration or inflammation but rather caused by disturbances in other brain areas or organs.

\section{Biochemical and Cellular Hepatic Alterations in the $\mathrm{NpC1}^{-/-} / \mathrm{Anxa6}^{-/-}$Mice}

Hepatomegaly, which is characterized by an increase in the hepatic index (liver weight/body weight), is another feature of NPC disease that was observed not only in $\mathrm{Npcl}^{-/-}$mice but also in the $\mathrm{Npcl}^{-1-} \mid \mathrm{Anxa6^{-/- }}$ animals compared with controls (WT and Anxa6 ${ }^{-1-}$ ) (Figure 3A). Hence, ANXA6 deficiency did not significantly add to the liver enlargement observed on NPC1 loss of function (Figure 4A).

As described previously, ${ }^{31}$ WT and Anxa6 ${ }^{-1-}$ animals had comparable values for markers of liver damage (Figure 4, $\mathrm{B}-\mathrm{F})$. However, we observed a significant increase in the serum aspartate, alanine aminotransferase, and alkaline phosphatase levels in $\mathrm{Npcl}^{-/-11}$ as well as $\mathrm{Npcl}^{-/-} / \mathrm{Anxa6}^{-/-}$ mice, implying increased hepatic damage and suggesting a further worsening of liver function in $\mathrm{Npcl}^{-/-}$mice on Anxa6 gene deletion. Next, we analyzed UC, triglycerides (TGs), free circulating fatty acids, and lipoprotein-associated cholesterol levels in the serum (Figure 4, G-K). Although total UC, high-density lipoprotein cholesterol, and fatty acids were comparable in all four mouse strains, low-density lipoprotein cholesterol was elevated in both $\mathrm{Npcl}^{-{ }_{-}}$and $\mathrm{Npcl}^{-/-}$/ Anxa6 ${ }^{-1-}$ animals (Figure 4K).

Given the multiple changes in hepatic cholesterol and TG metabolism in $\mathrm{Npcl}^{-1-}$ mice $^{11}$ and the link between ANXA6 and cholesterol transport, ${ }^{49}$ lipid droplet formation, ${ }^{50}$ and liver metabolism, ${ }^{31}$ we next determined UC and CEs as well as TG levels in liver homogenates. In line with previous reports, ${ }^{11,51,52}$ livers from NPC1-deficient animals contained highly elevated levels of UC (Figure 4L). Despite the recently observed restoration of cholesterol export in ANXA6-depleted Npcl mutant epithelial cells, ${ }^{21}$ UC levels remained highly elevated in $\mathrm{Npcl}^{-/-} / \mathrm{Anxa}^{-/-}$livers (Figure 4L). Remarkably, CEs were undetectable in 
A
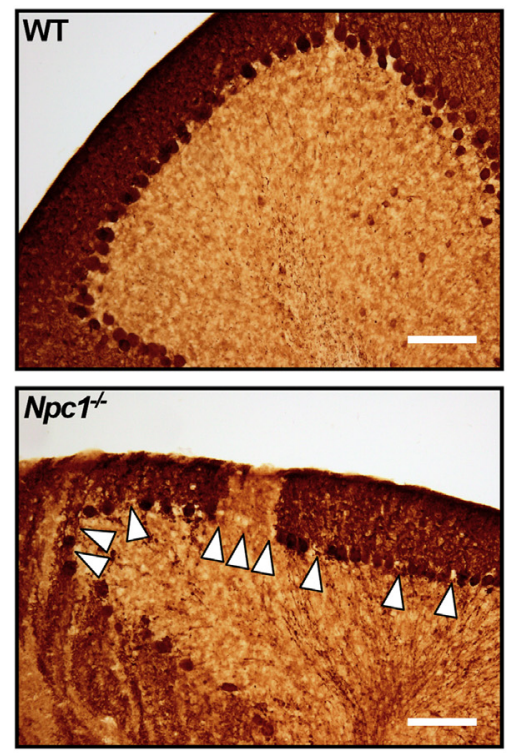

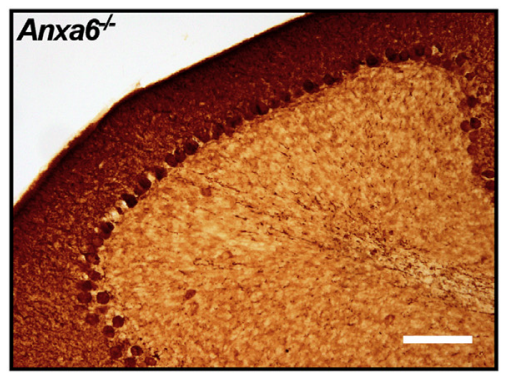

Npc1 $^{-1-/ A n \times a 6^{-1}}$

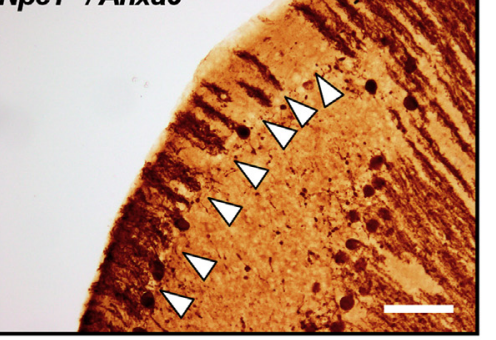

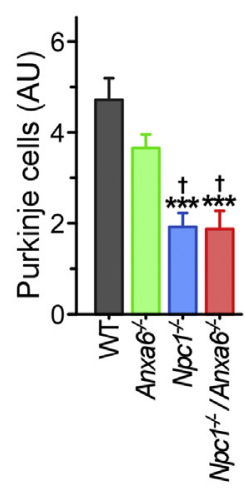

B
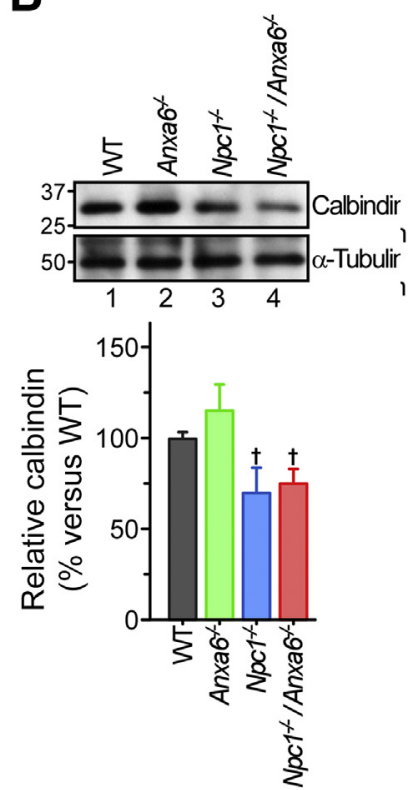

C
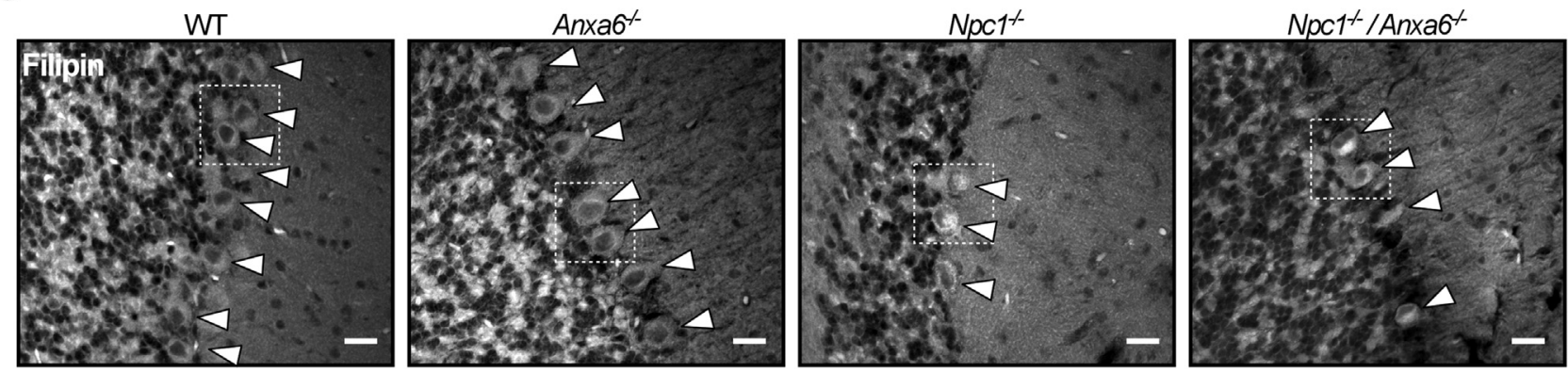

Figure 3 Cerebellar histologic analysis. A: Cerebellar Purkinje cell number was evaluated by immunohistochemistry using an anti-calbindin D-28k antibody. Representative images for each genotype are shown. Arrowheads point to large areas that lack Purkinje cells. B: Cerebellar calbindin expression was evaluated by Western blotting. Relative calbindin protein levels were quantified, normalized to $\alpha$-tubulin, and expressed relative to wild-type (WT) mice. Representative immunoblots are shown. C: Representative images of filipin staining of frozen brain sections showing the Purkinje cells of cerebellum. Arrowheads point the Purkinje cells. Boxed areas highlight differential staining. Data are expressed as means \pm SEM. $n=4$ per genotype (A); $n=7$ to 11 per genotype (B). ${ }^{* *} P<0.001$ versus WT mice; ${ }^{\dagger} P<0.05$ versus $A n x a 6^{-/-}$mice. Scale bars: $100 \mu \mathrm{m}(\mathbf{A}) ; 20 \mu \mathrm{m}(\mathbf{C})$.

$\mathrm{Npcl}^{-/-} / \mathrm{Anxa6^{-/- }}$ livers (Figure 4M), supporting a role for ANXA6 in cholesterol transport routes that involve CE hydrolysis in endolysosomes or lipid droplets, or reesterification of UC in the endoplasmic reticulum. Somewhat unexpectedly, hepatic TG levels in $\mathrm{Npcl}^{-/-} / \mathrm{Anxa6^{-/- }}$ mice were increased compared with the control (WT, Anxa6 ${ }^{-/-}$) and $\mathrm{Npcl}^{-/-}$animals (Figure $4 \mathrm{~N}$ ). ${ }^{51,52}$ In correlation with the elevated TG levels in $N p c 1^{-/-} / A_{n x a 6^{-/}}$livers (Figure $4 \mathrm{~N}$ ), circulating TG levels were slightly decreased in these animals (Figure $4 \mathrm{H}$ ).

Taken together, ANXA6 deficiency may influence cholesterol transport routes that involve cholesterol deesterification or /reesterification in the livers of $\mathrm{Npcl}^{-/-}$mice. In addition, elevated hepatic TG levels in $\mathrm{Npcl}^{-/}$, Anxa6 ${ }^{-1-}$ animals may indicate that loss of ANXA6 alters the impact of NPC1 deficiency on hepatic TG metabolism, ${ }^{51}$ and further analysis beyond the scope of this study would be required to address this point. In support of the biochemical data, filipin staining (as a readout of UC distribution and content) in frozen liver sections found a clearly increased fluorescence intensity only in $\mathrm{Npcl}^{-/-}$and $\mathrm{Npcl}^{-1}$ - $/ A n x A 6^{-/-}$samples (Supplemental Figure S3).

Next, liver histologic analysis in H\&E- and Masson's trichrome-stained samples from the same lobule of 8week-old animals were compared. As recently reported, the morphology and overall architecture of livers from WT and Anxa6 ${ }^{-{ }_{-}}$mice was comparable (Figure 5A)..$^{31,53}$ In contrast, liver sections from $\mathrm{Npcl}^{-/-}$and $\mathrm{Npcl}^{-/-}$, Anxa6 ${ }^{-1-}$ animals revealed an elevated number of pale foamy macrophages. Quantification of Masson's trichrome-stained sections identified an even higher abundance of these foam cells in $\mathrm{Npcl}^{-/-} / \mathrm{AnxaG}^{-/-}$liver 

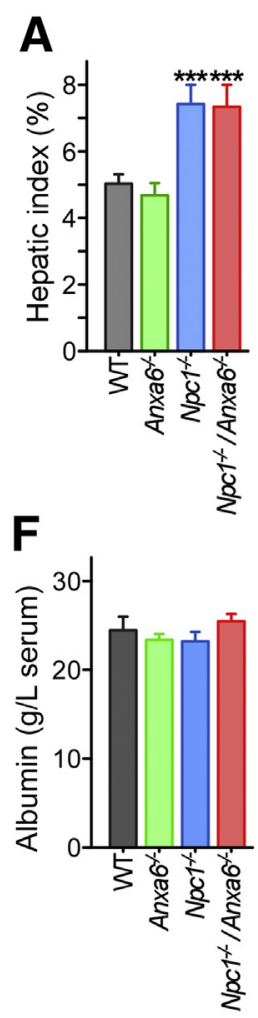

B

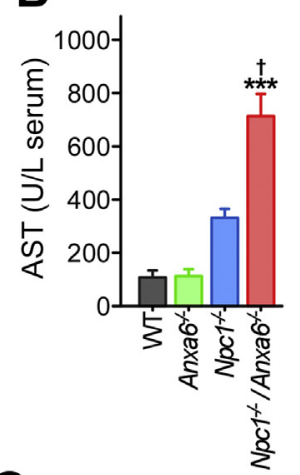

G

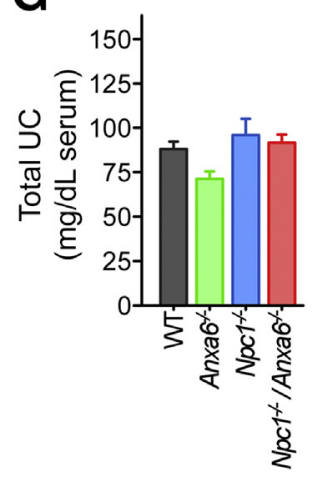

C

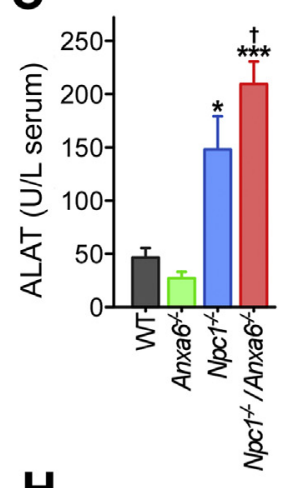

H

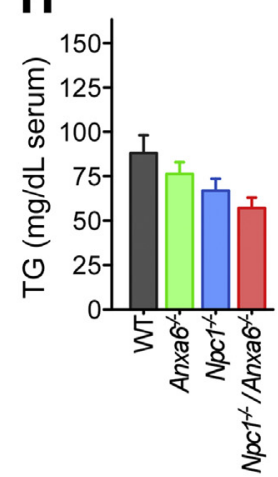

D
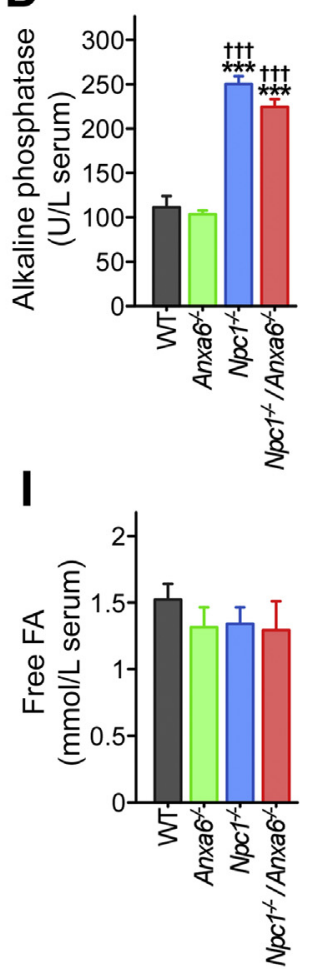

E

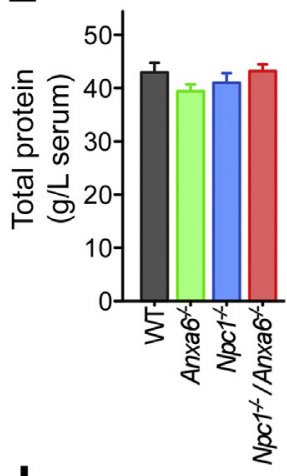

J

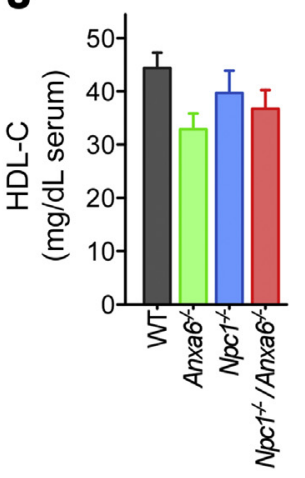

K

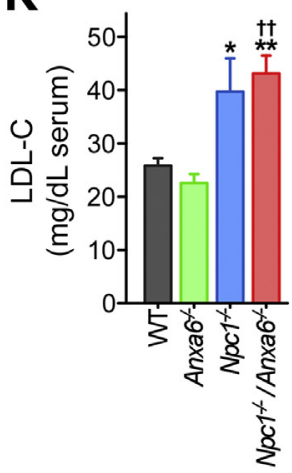

L

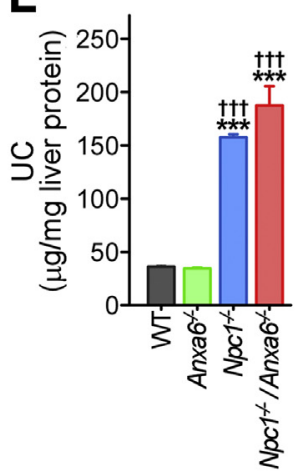

M

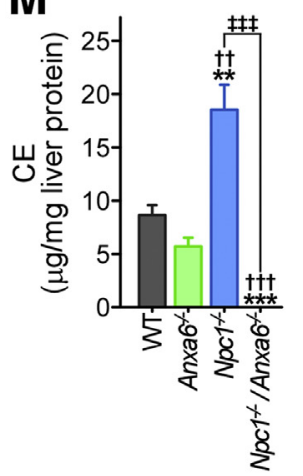

N

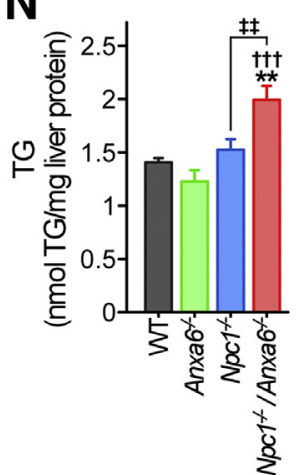

Figure 4 Analysis of hepatic function of 8-week-old $\mathrm{NpC}^{-/-} / \mathrm{Anxa6^{-/- }}$ mice. A: Hepatic index (liver weight/body weight $\left.\times 100\right)$ of the four genotypes is given as indicated. B-F: Serum levels of aspartate aminotransferase (AST), alanine aminotransferase (ALT), alkaline phosphatase, total protein, and albumin. G-K: Serum levels of total unesterified cholesterol (UC), triglycerides (TG), free fatty acids (FA), high-density lipoprotein cholesterol (HDL-C), and low-density lipoprotein cholesterol (LDL-C). L-N: Hepatic UC, esterified cholesterol (EC), and TG levels. Data are expressed as means \pm SEM. $n=6$ per group (A); $n=6$ to 11 per genotype $(\mathbf{B}-\mathbf{F}) ; n=6$ to 11 per group $(\mathbf{G}-\mathbf{K}) ; n=6$ to 11 per group $(\mathbf{L}-\mathbf{N})$. ${ }^{*} P<0.05, * * P<0.01$, and ${ }^{* * *} P<0.001$ versus wild-type (WT) mice; ${ }^{\dagger} P<0.05,{ }^{\dagger \dagger} P<0.01$, and ${ }^{\dagger \dagger} P<0.001$ versus $A n x a 6^{-/-}$mice; ${ }^{\ddagger \ddagger} P<0.01$, ${ }^{\ddagger \ddagger \ddagger} P<0.001$.

sections compared with $\mathrm{Npcl}^{-1-}$ animals (approximately 20\%) (Figure 5B). Together with the swelling of hepatocytes, this produced an obliteration of sinusoidal spaces all over the acinus.

The important increment of Kupffer cells in $\mathrm{Npcl}^{-/-}$and $\mathrm{NpCl}^{-/-} / \mathrm{Anxa6}^{-/-}$livers prompted us to analyze the inflammatory response by the assessment of the expression levels of three proinflammatory cytokines. Quantitative RTPCR analysis clearly found a significant increase of Tnf mRNA levels detected in the livers of $\mathrm{Npcl}^{-/-}$and $\mathrm{Npcl}^{-1-}$ / Anxa $6^{-/-}$mice but very low levels of Illb and no significant changes of $I l 6$ (Supplemental Figure S4). Therefore, elevated
Tnf (probably from dendritic and Kupffer cells) seems to not be responsible for trigger hepatic inflammation or production of Il6 by hepatic stellate cells. Further work is necessary to elucidate the consequence of decreased Tnf levels in the $\mathrm{NpCl}^{-/-} / \mathrm{Anxa6}^{-1-}$ (Supplemental Figure S4B) in the context of hepatic physiology.

Finally, ultrastructural analysis of 8-week-old mice livers (Figure 5C) confirmed the normal architecture of hepatocytes and sinusoidal cells and spaces in WT and Anxa6 $6^{-1-}$ livers. However, in $\mathrm{Npcl}^{-/-}$and $\mathrm{Npcl}^{-1-}$ / Anxa $6^{-1-}$ micrographs, a drastic alteration of the liver plate architecture was evident. As with the H\&E- and Masson's 


\section{A}
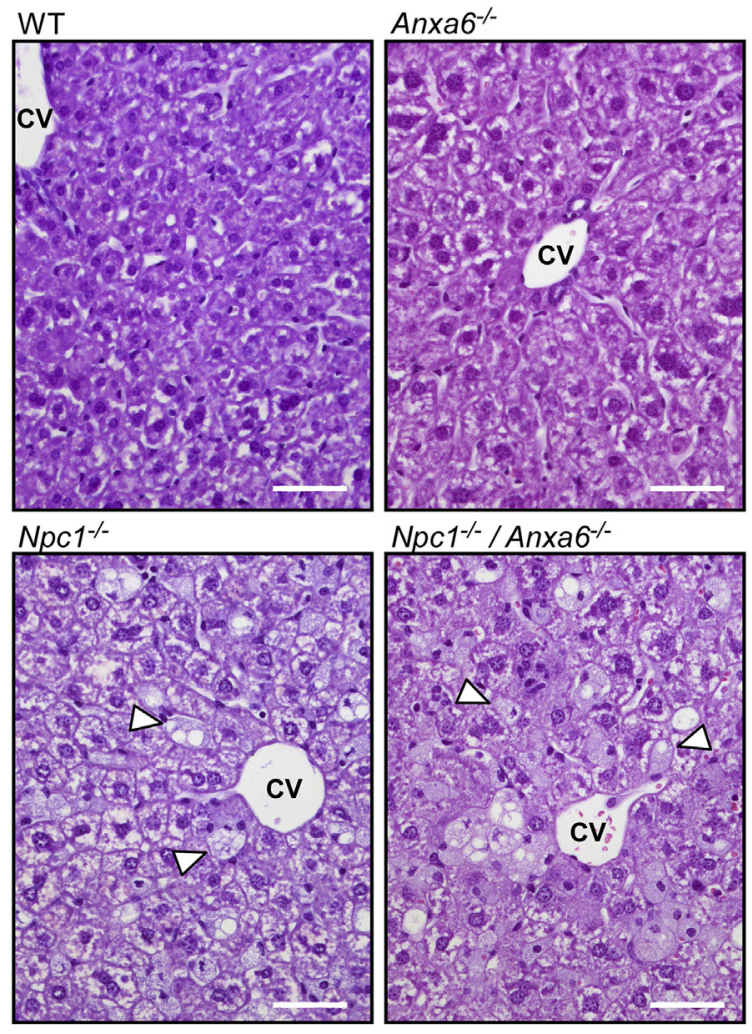

B

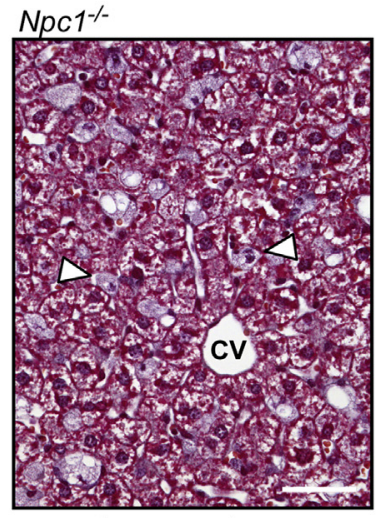

Npc1\% / Anxa6 $\%$

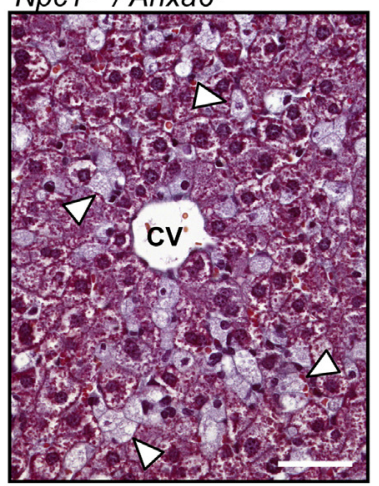

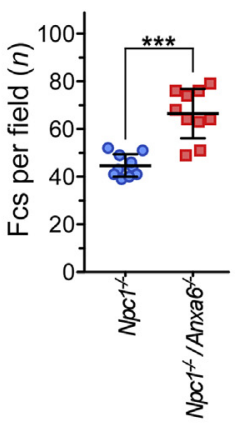

C
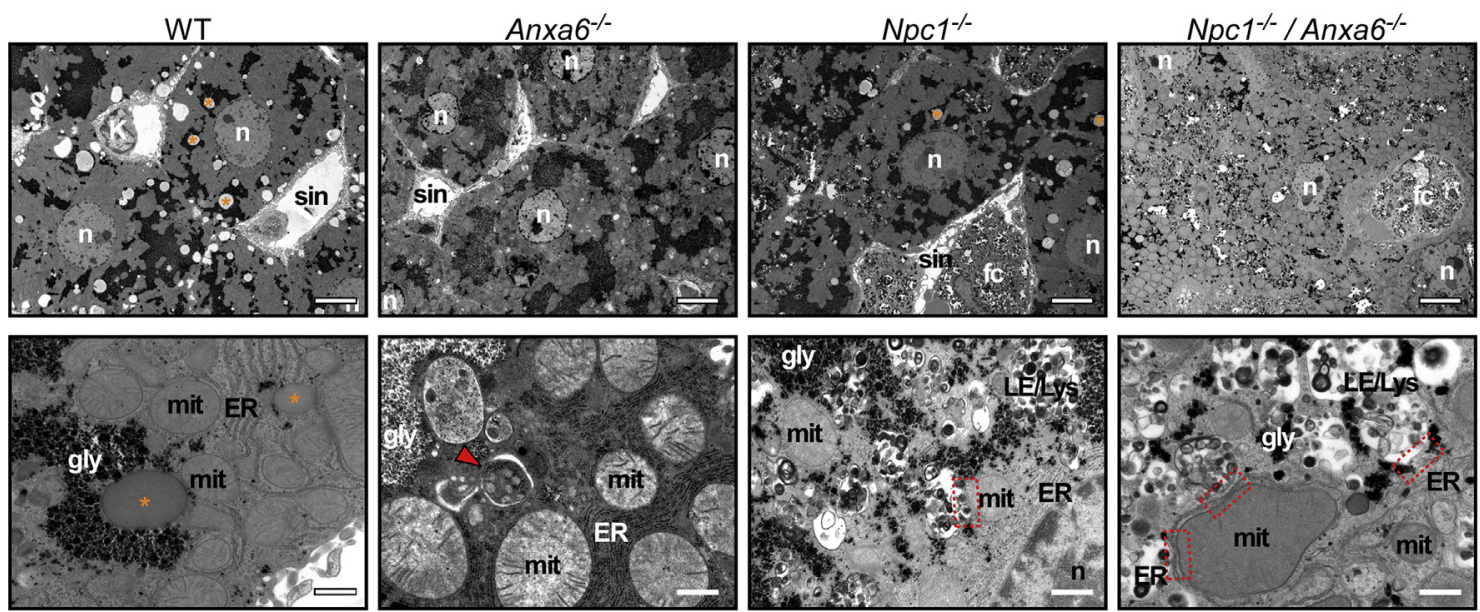

Figure 5 Liver histologic analysis of 8-week-old $\mathrm{Npc1}^{-/-} / \mathrm{Anxa6}^{-/-}$mice. A: Representative hematoxylin and eosin staining of wild-type (WT), Anxa6 ${ }^{-/-}$, $\mathrm{NpC1}^{-/-}$, and $\mathrm{NpC1}^{-/-} / \mathrm{Anxa6}^{-/-}$liver sections. Arrowheads indicate foam cells (fcs). Scale B: Representative Masson's trichrome staining of Npc1 ${ }^{-/-}$and $\mathrm{NpC1}^{-/-} /$ Anxa $6^{-1-}$ liver sections. Arrowheads indicate fcs. The number of fcs per field were quantified. C: Representative electron microscopy images of WT, Anxa6 ${ }^{-1-}, \mathrm{Npc1}^{-/-}$ and $\mathrm{Npc1}^{-/-} / \mathrm{Anxa}^{-/-}$liver sections. Asterisk indicates lipid droplets. The red arrowhead points to the autophagosome, and boxed areas indicate the endoplasmic reticulum (ER)-mitochondria (mit)-endolysosome (LE/Lys) contact sites. Data are expressed as means \pm SD. $n=10$ to $11 \mathrm{fcs}$ per group (B); *** $P<0.001$ compared $\mathrm{Npc1}^{-/-}$to $\mathrm{Npc1}{ }^{-/-} / \mathrm{Anxa6}^{-/-}$mice. Scale bars: $50 \mu \mathrm{m}$ (B); $5 \mu \mathrm{m}$ (C, top row); $0.5 \mu \mathrm{m}$ (C, bottom row). CV, central vein; gly, glycogen; $\mathrm{K}$, Kupffer cell; LE, late endosome; Lys, Lysosome; mit, mitochondria; $n$, nucleus; sin, sinusoidal space.

trichrome-stained sections (Figure 5, A and B), enlarged hepatocytes and an obliteration of sinusoidal spaces attributable to the increased number and size of foam cells (Kupffer cells) was evident. At high magnification, enlarged, rounded and less electron-dense mitochondria in the $A n x a 6^{-1-}$ livers were observed, which may reflect observations from others reporting compromised mitochondrial morphogenesis in liver, retina, and primary fibroblasts 
from Anxa6 ${ }^{-1-}$ mice. ${ }^{54}$ In addition, a prominent presence of prototypical endolysosomes with multilamellar and electron-dense, vacuole-like structures in hepatocytes but also nonparenchymal cells in both $\mathrm{Npcl}^{-/-}$and $\mathrm{Npcl}^{-1-}$ / Anxa6 ${ }^{-1-}$ livers was apparent. This striking morphologic feature is believed to be triggered by the lack of NPC1, causing an enlargement of this compartment attributable to the accumulation of cholesterol, sphingomyelin, and other lipids. In addition, the number of lipid droplets and glycogen granules, the latter being abundant in $\mathrm{Npcl}^{-/-}$ livers (Figure 5C), was strongly decreased in $\mathrm{Npcl}^{-1-}$, Anxa6 ${ }^{-1-}$ hepatocytes compared with those from $\mathrm{Npcl}^{-1-}$ animals. These findings could indicate a higher glycogen consumption and be possibly related to the metabolic difficulties with hepatic glucose homeostasis observed during liver regeneration and high-fat feeding of ANXA6-deficient animals. ${ }^{31,53}$ In addition, and in line with increasing evidence for altered interorganelle communication in cells lacking NPC1 and/or ANXA6, ${ }^{55}$ the liver of $\mathrm{Npcl}^{-1-}$ and $\mathrm{Npcl}^{-/-} / \mathrm{Anxa6^{-/- }}$ mice also revealed endolysosomes in close contact with mitochondria and mitochondria surrounded by endoplasmic reticulum and endolysosomes in a $\mathrm{Npcl}^{-/-} /$Anxa6 $\mathrm{6}^{-/-}$hepatocyte.

\section{Discussion}

During the last three decades, several murine as well as other $\mathrm{NpCl}^{-1-}$ animal models have proven valuable for the dissection of the physiologic defects and pathology associated with NPC disease. ${ }^{5-59}$ We found that, while ANXA6

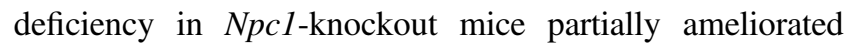
some sensory and physical phenotypes, other aspects of motor coordination worsened. $N p c 1^{-/-} /$Anxa6 $6^{-1-}$ mice had a decreased lifespan compared with $\mathrm{Npcl}^{-/-}$mice. This was not a consequence of increased cerebellar degeneration but correlated with aggravated liver damage in NPC1-deficient animals lacking ANXA6. Highly elevated numbers and size of foam cells congesting the sinusoidal space in $\mathrm{NpCl}^{-/-} / \mathrm{Anxa6^{-/- }}$ livers indicate upregulated inflammatory events, suggesting that ANXA6 deficiency in Npcl knockout mice exacerbates hepatic malfunction in NPC disease. However, we cannot rule out that decreased survival in the $\mathrm{Npcl}^{-/-} / \mathrm{Anxa6^{-/- }}$ mice could also be influenced by damage to other areas in the CNS not analyzed in this study because only restoration of NPC1 expression in the CNS was able to restore a normal lifespan in NPC1deficient animals. ${ }^{60}$ Moreover, because different genetic backgrounds have dissimilar consequences for $\mathrm{Npcl}$ knockout mice lifespan, ${ }^{19,61-63}$ we cannot dismiss a role of the genetic background in reduced $\mathrm{Npcl}^{-/-} / \mathrm{Anxa6^{-/- }}$ mice survival.

Recently, we found that ANXA6 depletion reduced cholesterol accumulation in endolysosomes and reestablished interorganelle communication in cell lines lacking NPC1. ${ }^{21}$ Hence, ANXA6 deficiency may overcome some pathologic features in NPC1-deficient mice. Indeed, SHIRPA analysis revealed a partial amelioration of sensory capabilities and an improvement in muscular strength in $\mathrm{Npcl}^{-/-} / \mathrm{Anxa}^{-/-}$, whereas other aspects of motor coordination were worsened in $\mathrm{Npcl}^{-1-} \mid \mathrm{Anxa6^{-1- }}$ mice as compared with those in $\mathrm{Npcl}^{-/-}$mice. These results suggest that behavioral and motor coordination defects in $\mathrm{Npcl}^{-/-}$ mice may be differentially regulated by ANXA6-dependent and -independent cholesterol export routes from endolysosomes to other specific organelles. Interestingly, ANXA6 deficiency did not prevent loss of Purkinje cells in $\mathrm{Npcl}^{-/-}$ animals, a hallmark of cerebellar neurodegeneration in NPC disease. In addition, $\mathrm{Npcl}^{-/-}$and $\mathrm{Npcl}^{-1-} \mid \mathrm{Anxa6^{-/- }}$ mice had similar levels of cerebellar neuroinflammation, previously reported to contribute to the $\mathrm{NpCl}^{-1-}$ mice phenotype. ${ }^{64}$ Altogether, these results suggest that worsening of motor coordination and decreased lifespan in $\mathrm{Npcl}^{-/}$ - $/$ Anxa $6^{-1-}$ mice might be attributable to complications in other areas of the CNS and other organs rather than the cerebellum.

Although the elevated hepatic cholesterol content in $\mathrm{Npcl}^{-1-} / \mathrm{Anxa6}^{-1-}$ mice was comparable to those from $\mathrm{Npcl}^{-1-}$ animals, ${ }^{11,51,52}$ a markedly elevated number of foam (Kupffer) cells filled with an increased quantity of endolysosomes and complex multilamellar structures was identified. These morphologic changes could be related to an altered RAB7 activity. Interestingly, ANXA6-depleted $\mathrm{Npcl}$ mutant cells are characterized by elevated RAB7 activity, the master regulator of late endosomal functionality. Downregulation of RAB7 activity also occurs during liver steatosis induced by a cholesterol-rich $\operatorname{diet}^{65}$ or ethanol exposure, ${ }^{66}$ and correlates with impaired fusion of the autophagic machinery with lipid droplets, leading to an accumulation of hepatocellular lipids. ${ }^{66}$

A remarkable feature of $\mathrm{Npcl}^{-/-} / \mathrm{Anxa6^{-/- }}$ livers was the substantially decreased number of lipid droplets and glycogen granules, indicating a much higher turnover of neutral lipids and glycogen compared with the $\mathrm{Npcl}^{-1-}$ animals. These morphologic changes correlated with the drastic reduction in the amount of cholesteryl esters, suggesting that ANXA6 deficiency in Npcl-ko mice indeed alters steps in cholesterol transport in endolysosomes, the endoplasmic reticulum, and/or lipid droplets, where deesterification and reesterification of cholesterol occurs. In addition, we and others found, by confocal and electron microscopy, morphologic alterations in mitochondria of hepatocytes from $\mathrm{NpCl}^{-/-67}$ and $A n x a 6^{-/-}$mice $^{54}$ possibly as a consequence of the increased cholesterol levels in the liver ${ }^{68}$ but also indicative of the detrimental $\mathrm{Ca}^{2+}$ signaling and respiration of these animals. ${ }^{54}$ In line with the decrease in cholesterol levels in $\mathrm{Npcl}^{-/-} / \mathrm{Anxa6}^{-1-}$ mice and in agreement with recent publications, ${ }^{21,22,55}$ we noticed a slight improvement of mitochondria morphology in close contact with the endoplasmic reticulum in the livers from 8week-old $\mathrm{Npcl}^{-/-} / \mathrm{Anxa6}^{-/-}$mice. 
The drastically increased number of foam (Kupffer) cells in $\mathrm{Npcl}^{-/-} / \mathrm{Anxa}^{-/-}$livers indicates inflammatory events that exacerbate hepatic dysfunction possibly explaining the significantly reduced lifespan of these animals. However, the role of inflammation in NPC liver dysfunction is still controversial and nonprotective, but protective roles of inflammatory macrophages in NPC livers have also been reported. ${ }^{7,20,69-72}$ A plausible explanation could be that hepatic macrophage subpopulations, including yolk sac-derived resident Kupffer cells, bone marrow monocyte-derived macrophages, and peritoneal macrophages $^{73}$ differentially contribute to beneficial or detrimental effects on liver damage. However, although transplanted bone marrow-derived mesenchymal stem cells can prevent the loss of $\mathrm{Npcl}^{-1-}$ mouse Purkinje neurons by correcting sphingolipid metabolism, this had no major effect on mouse survival, suggesting rather minor function in the overall animal pathology. ${ }^{74}$

Kupffer cells could indeed be central to the aggravated inflammation in $\mathrm{Npcl}^{-1-} / \mathrm{Anxa6^{-1- }}$ livers because they respond to hepatocyte injuries via activation of NF- $\kappa \mathrm{B}$ -dependent proinflammatory cytokine secretion. In fact, Kupffer cell depletion not only prevented the development of nonalcoholic steatohepatitis ${ }^{75,76}$ but also partially rescued NPC liver damage, ${ }^{14}$ the latter correlating with inhibition of NF- $\kappa \mathrm{B}$-dependent inflammatory events. ${ }^{77}$ In $\mathrm{Npcl}^{-/-}$/ Anxa6 ${ }^{-1-}$ livers, ANXA6 deficiency may facilitate increased recruitment of infiltrating monocytes or promote proliferation of resident Kupffer cells in the perivenous region, leading to an elevated cytokine release and cytotoxic activity. ${ }^{16}$ The underlying mechanism remains to be clarified, but the infiltration of monocyte-derived or peritoneal macrophages, which are recruited on tissue damage $\mathrm{e}^{73}$ and actively secrete cytokines and have high cytotoxic capacity ${ }^{16}$ appears as a feasible cause. In addition, the ability of ANXA6 to modulate tumor necrosis factor secretion ${ }^{78}$ and to bind to the $\mathrm{p} 65$ subunit of NF- $\kappa \mathrm{B}^{79}$ may contribute to the phenotype observed here.

Highly elevated lipid storage in hepatic endolysosomes is a hallmark of NPC disease, ${ }^{9,46}$ with Kupffer cells out of the liver cell population displaying the most pronounced lipid storage. Although restoration of hepatic NPC1 expression in $\mathrm{NpCl}^{-/-}$reduced liver inflammation and foamy appearance of Kupffer cells, this did not correlate with an increased lifespan of mice with NPC disease. ${ }^{20}$ On the basis of this study, we speculate that lack of ANXA6 in $\mathrm{Npcl}^{-/-}$mice is detrimental for hepatic physiology and related to a Kupffer cell-dependent inflammatory response.

\section{Acknowledgments}

We thank the staff of Centers Científics i Tecnològics, Universitat de Barcelona, Unitat d'Experimentació Animal, Unitat de Microscòpia Òptica Avançada, and Unitat de Microscòpia Electrònica.

\section{Supplemental Data}

Supplemental material for this article can be found at http://doi.org/10.1016/j.ajpath.2020.12.009.

\section{References}

1. Blanchette-Mackie EJ: Intracellular cholesterol trafficking: role of the NPC1 protein. Biochim Biophys Acta 2000, 1486:171-183

2. Klein $\mathrm{AD}$, Alvarez A, Zanlungo $\mathrm{S}$ : The unique case of the NiemannPick type C cholesterol storage disorder. Pediatr Endocrinol Rev 2014, 12 Suppl 1:166-175

3. Hammond N, Munkacsi AB, Sturley SL: The complexity of a monogenic neurodegenerative disease: more than two decades of therapeutic driven research into Niemann-Pick type C disease. Biochim Biophys Acta Mol Cell Biol Lipids 2019, 1864:1109-1123

4. Loftus SK, Morris JA, Carstea ED, Gu JZ, Cummings C, Brown A Ellison J, Ohno K, Rosenfeld MA, Tagle DA, Pentchev PG, Pavan WJ: Murine model of Niemann-Pick C disease: mutation in a cholesterol homeostasis gene. Science 1997, 277:232-235

5. Elrick MJ, Pacheco CD, Yu T, Dadgar N, Shakkottai VG, Ware C, Paulson HL, Lieberman AP: Conditional Niemann-Pick C mice demonstrate cell autonomous Purkinje cell neurodegeneration. Hum Mol Genet 2010, 19:837-847

6. Rimkunas VM, Graham MJ, Crooke RM, Liscum L: In vivo antisense oligonucleotide reduction of NPC1 expression as a novel mouse model for Niemann Pick type C- associated liver disease. Hepatology 2008, 47:1504-1512

7. Rimkunas VM, Graham MJ, Crooke RM, Liscum L: TNF-\{alpha $\}$ plays a role in hepatocyte apoptosis in Niemann-Pick type C liver disease. J Lipid Res 2009, 50:327-333

8. Vazquez MC, del Pozo T, Robledo FA, Carrasco G, Pavez L, Olivares F, Gonzalez M, Zanlungo S: Alteration of gene expression profile in Niemann-Pick type $\mathrm{C}$ mice correlates with tissue damage and oxidative stress. PLoS One 2011, 6:e28777

9. Vanier MT: Niemann-Pick diseases. Handb Clin Neurol 2013, 113 : $1717-1721$

10. Ebner L, Glaser A, Brauer A, Witt M, Wree A, Rolfs A, Frank M, Vollmar B, Kuhla A: Evaluation of two liver treatment strategies in a mouse model of Niemann-Pick-disease type C1. Int J Mol Sci 2018, 19:972

11. Beltroy EP, Richardson JA, Horton JD, Turley SD, Dietschy JM: Cholesterol accumulation and liver cell death in mice with NiemannPick type C disease. Hepatology 2005, 42:886-893

12. Sayre NL, Rimkunas VM, Graham MJ, Crooke RM, Liscum L: Recovery from liver disease in a Niemann-Pick type $\mathrm{C}$ mouse model. J Lipid Res 2010, 51:2372-2383

13. Brauer AU, Kuhla A, Holzmann C, Wree A, Witt M: Current challenges in understanding the cellular and molecular mechanisms in Niemann-Pick disease type C1. Int J Mol Sci 2019, 20:4392

14. Klein AD, Oyarzun JE, Cortez C, Zanlungo S: Gadolinium chloride rescues Niemann(-)Pick type C liver damage. Int J Mol Sci 2018, 19

15. Kubes P, Jenne C: Immune responses in the liver. Annu Rev Immunol 2018, 36:247-277

16. Sleyster EC, Knook DL: Relation between localization and function of rat liver Kupffer cells. Lab Invest 1982, 47:484-490

17. Kuiper JB A, Knook DL, van Berkel TJC: Kupffer and sinusoidal endothelial cells. The Liver Biology and Pathobiology. Edited by Arias JLB IM, Fausto N, Jakoby WB, Schachter DA, Shafritz DA. ed 3. New York: Raven Press, 1994. pp. 791-818

18. Meneses-Salas E, Garcia-Melero A, Blanco-Munoz P, Jose J, Brenner MS, Lu A, Tebar F, Grewal T, Rentero C, Enrich C: Selective degradation permits a feedback loop controlling annexin A6 and cholesterol levels in endolysosomes of NPC1 mutant cells. Cells 2020, 9 
19. Bosch M, Fajardo A, Alcala-Vida R, Fernandez-Vidal A, Tebar F, Enrich C, Cardellach F, Perez-Navarro E, Pol A: Hepatic primary and secondary cholesterol deposition and damage in Niemann-Pick disease. Am J Pathol 2016, 186:517-523

20. Lopez ME, Klein AD, Hong J, Dimbil UJ, Scott MP: Neuronal and epithelial cell rescue resolves chronic systemic inflammation in the lipid storage disorder Niemann-Pick C. Hum Mol Genet 2012, 21 : 2946-2960

21. Meneses-Salas E, Garcia-Melero A, Kanerva K, Blanco-Munoz P, Morales-Paytuvi F, Bonjoch J, Casas J, Egert A, Beevi SS, Jose J, Llorente-Cortes V, Rye KA, Heeren J, Lu A, Pol A, Tebar F, Ikonen E, Grewal T, Enrich C, Rentero C: Annexin A6 modulates TBC1D15/Rab7/StARD3 axis to control endosomal cholesterol export in NPC1 cells. Cell Mol Life Sci 2020, 77:2839-2857

22. Hoglinger D, Burgoyne T, Sanchez-Heras E, Hartwig P, Colaco A, Newton J, Futter CE, Spiegel S, Platt FM, Eden ER: NPC1 regulates ER contacts with endocytic organelles to mediate cholesterol egress. Nat Commun 2019, 10:4276

23. Pfeffer SR: Clues to NPC1-mediated cholesterol export from lysosomes. Proc Natl Acad Sci U S A 2016, 113:7941-7943

24. Gerke V, Creutz CE, Moss SE: Annexins: linking Ca2 + signalling to membrane dynamics. Nat Rev Mol Cell Biol 2005, 6:449-461

25. Tagoe CE, Boustead CM, Higgins SJ, Walker JH: Characterization and immunolocalization of rat liver annexin VI. Biochim Biophys Acta 1994, 1192:272-280

26. Moga MM, Zhou D: Annexin 6 immunoreactivity in select cell populations in the rat brain. J Histochem Cytochem 2002, 50: $1277-1280$

27. Jackle S, Beisiegel U, Rinninger F, Buck F, Grigoleit A, Block A, Groger I, Greten H, Windler E: Annexin VI, a marker protein of hepatocytic endosomes. J Biol Chem 1994, 269:1026-1032

28. Ortega D, Pol A, Biermer M, Jackle S, Enrich C: Annexin VI defines an apical endocytic compartment in rat liver hepatocytes. J Cell Sci 1998, 111(Pt 2):261-269

29. Enrich C, Pol A, Calvo M, Pons M, Jackle S: Dissection of the multifunctional "receptor-recycling" endocytic compartment of hepatocytes. Hepatology 1999, 30:1115-1120

30. Enrich C, Rentero C, Grewal T: Annexin A6 in the liver: from the endocytic compartment to cellular physiology. Biochim Biophys Acta Mol Cell Res 2017, 1864:933-946

31. Alvarez-Guaita A, Blanco-Munoz P, Meneses-Salas E, Wahba M, Pollock AH, Jose J, Casado M, Bosch M, Artuch R, Gaus K, Lu A, Pol A, Tebar F, Moss SE, Grewal T, Enrich C, Rentero C: Annexin A6 is critical to maintain glucose homeostasis and survival during liver regeneration in mice. Hepatology 2020, 72: 2149-2164

32. Hawkins TE, Roes J, Rees D, Monkhouse J, Moss SE: Immunological development and cardiovascular function are normal in annexin VI null mutant mice. Mol Cell Biol 1999, 19: 8028-8032

33. Anglada-Huguet $\mathrm{M}$, Xifro $\mathrm{X}$, Giralt A, Zamora-Moratalla A, Martin ED, Alberch J: Prostaglandin E2 EP1 receptor antagonist improves motor deficits and rescues memory decline in R6/1 mouse model of Huntington's disease. Mol Neurobiol 2014, 49:784-795

34. Giralt A, Saavedra A, Carreton O, Xifro X, Alberch J, PerezNavarro E: Increased PKA signaling disrupts recognition memory and spatial memory: role in Huntington's disease. Hum Mol Genet 2011, 20:4232-4247

35. Liao G, Yao Y, Liu J, Yu Z, Cheung S, Xie A, Liang X, Bi X: Cholesterol accumulation is associated with lysosomal dysfunction and autophagic stress in Npc1 -/- mouse brain. Am J Pathol 2007, 171:962-975

36. Rue L, Banez-Coronel M, Creus-Muncunill J, Giralt A, AlcalaVida R, Mentxaka G, Kagerbauer B, Zomeno-Abellan MT, Aranda Z, Venturi V, Perez-Navarro E, Estivill X, Marti E: Targeting CAG repeat RNAs reduces Huntington's disease phenotype independently of huntingtin levels. J Clin Invest 2016, 126:4319-4330
37. Schindelin J, Arganda-Carreras I, Frise E, Kaynig V, Longair M, Pietzsch T, Preibisch S, Rueden C, Saalfeld S, Schmid B, Tinevez JY, White DJ, Hartenstein V, Eliceiri K, Tomancak P, Cardona A: Fiji: an open-source platform for biological-image analysis. Nat Methods 2012, 9:676-682

38. Spisak T, Roman V, Papp E, Kedves R, Saghy K, Csolle CK, Varga A, Gajari D, Nyitrai G, Spisak Z, Kincses ZT, Levay G, Lendvai B, Czurko A: Purkinje cell number-correlated cerebrocerebellar circuit anomaly in the valproate model of autism. Sci Rep 2019, 9:9225

39. Schmittgen TD, Livak KJ: Analyzing real-time PCR data by the comparative C(T) method. Nat Protoc 2008, 3:1101-1108

40. Rogers DC, Fisher EM, Brown SD, Peters J, Hunter AJ, Martin JE: Behavioral and functional analysis of mouse phenotype: SHIRPA, a proposed protocol for comprehensive phenotype assessment. Mamm Genome 1997, 8:711-713

41. Blazquez G, Canete T, Tobena A, Gimenez-Llort L, FernandezTeruel A: Cognitive and emotional profiles of aged Alzheimer's disease $(3 \times \mathrm{Tg} \mathrm{AD})$ mice: effects of environmental enrichment and sexual dimorphism. Behav Brain Res 2014, 268:185-201

42. Brooks SP, Dunnett SB: Tests to assess motor phenotype in mice: a user's guide. Nat Rev Neurosci 2009, 10:519-529

43. Creus-Muncunill J, Badillos-Rodriguez R, Garcia-Forn M, Masana M, Garcia-Diaz Barriga G, Guisado-Corcoll A, Alberch J, Malagelada C, Delgado-Garcia JM, Gruart A, Perez-Navarro E: Increased translation as a novel pathogenic mechanism in Huntington's disease. Brain 2019, 142:3158-3175

44. Vance JE: Lipid imbalance in the neurological disorder, NiemannPick C disease. FEBS Lett 2006, 580:5518-5524

45. Vincent I, Bu B, Erickson RP: Understanding Niemann-Pick type C disease: a fat problem. Curr Opin Neurol 2003, 16:155-161

46. Ikonen E, Holtta-Vuori M: Cellular pathology of Niemann-Pick type C disease. Semin Cell Dev Biol 2004, 15:445-454

47. Voikar V, Rauvala H, Ikonen E: Cognitive deficit and development of motor impairment in a mouse model of Niemann-Pick type $\mathrm{C}$ disease. Behav Brain Res 2002, 132:1-10

48. Alvarez AR, Klein A, Castro J, Cancino GI, Amigo J, Mosqueira M, Vargas LM, Yevenes LF, Bronfman FC, Zanlungo S: Imatinib therapy blocks cerebellar apoptosis and improves neurological symptoms in a mouse model of Niemann-Pick type C disease. FASEB J 2008, 22:3617-3627

49. Enrich C, Rentero C, de Muga SV, Reverter M, Mulay V, Wood P, Koese M, Grewal T: Annexin A6-linking $\mathrm{Ca}(2+)$ signaling with cholesterol transport. Biochim Biophys Acta 2011, 1813:935-947

50. Cairns R, Alvarez-Guaita A, Martinez-Saludes I, Wason SJ, Hanh J, Nagarajan SR, Hosseini-Beheshti E, Monastyrskaya K, Hoy AJ, Buechler C, Enrich C, Rentero C, Grewal T: Role of hepatic annexin A6 in fatty acid-induced lipid droplet formation. Exp Cell Res 2017, 358:397-410

51. Uronen RL, Lundmark $\mathrm{P}$, Orho-Melander $\mathrm{M}$, Jauhiainen $\mathrm{M}$, Larsson K, Siegbahn A, Wallentin L, Zethelius B, Melander O, Syvanen AC, Ikonen E: Niemann-Pick C1 modulates hepatic triglyceride metabolism and its genetic variation contributes to serum triglyceride levels. Arterioscler Thromb Vasc Biol 2010, 30: $1614-1620$

52. Kulinski A, Vance JE: Lipid homeostasis and lipoprotein secretion in Niemann-Pick C1-deficient hepatocytes. J Biol Chem 2007, 282: $1627-1637$

53. Cairns R, Fischer AW, Blanco-Munoz P, Alvarez-Guaita A, Meneses-Salas E, Egert A, Buechler C, Hoy AJ, Heeren J, Enrich C, Rentero C, Grewal T: Altered hepatic glucose homeostasis in AnxA6-KO mice fed a high-fat diet. PLoS One 2018, 13: e0201310

54. Chlystun M, Campanella M, Law AL, Duchen MR, Fatimathas L, Levine TP, Gerke V, Moss SE: Regulation of mitochondrial morphogenesis by annexin A6. PLoS One 2013, 8:e53774 
55. Enrich C, Rentero C, Grewal T, Futter CE, Eden ER: Cholesterol overload: contact sites to the rescue! Contact (Thousand Oaks) 2019, 2. 2515256419893507

56. Fog CK, Kirkegaard T: Animal models for Niemann-Pick type C: implications for drug discovery \& development. Expert Opin Drug Discov 2019, 14:499-509

57. Maue RA, Burgess RW, Wang B, Wooley CM, Seburn KL, Vanier MT, Rogers MA, Chang CC, Chang TY, Harris BT, Graber DJ, Penatti CA, Porter DM, Szwergold BS, Henderson LP, Totenhagen JW, Trouard TP, Borbon IA, Erickson RP: A novel mouse model of Niemann-Pick type C disease carrying a D1005GNpc1 mutation comparable to commonly observed human mutations. Hum Mol Genet 2012, 21:730-750

58. Pentchev PG: Niemann-Pick $C$ research from mouse to gene. Biochim Biophys Acta 2004, 1685:3-7

59. Praggastis M, Tortelli B, Zhang J, Fujiwara H, Sidhu R, Chacko A, Chen Z, Chung C, Lieberman AP, Sikora J, Davidson C, Walkley SU, Pipalia NH, Maxfield FR, Schaffer JE, Ory DS: A murine Niemann-Pick C1 I1061T knock-in model recapitulates the pathological features of the most prevalent human disease allele. $\mathrm{J}$ Neurosci 2015, 35:8091-8106

60. Loftus SK, Erickson RP, Walkley SU, Bryant MA, Incao A, Heidenreich RA, Pavan WJ: Rescue of neurodegeneration in Niemann-Pick C mice by a prion-promoter-driven Npc1 cDNA transgene. Hum Mol Genet 2002, 11:3107-3114

61. Gomez-Grau M, Albaiges J, Casas J, Auladell C, Dierssen M, Vilageliu L, Grinberg D: New murine Niemann-Pick type C models bearing a pseudoexon-generating mutation recapitulate the main neurobehavioural and molecular features of the disease. Sci Rep 2017, 7:41931

62. Parra J, Klein AD, Castro J, Morales MG, Mosqueira M, Valencia I, Cortes V, Rigotti A, Zanlungo S: Npc1 deficiency in the C57BL/6J genetic background enhances Niemann-Pick disease type $\mathrm{C}$ spleen pathology. Biochem Biophys Res Commun 2011, 413:400-406

63. Rodriguez-Gil JL, Watkins-Chow DE, Baxter LL, Elliot G, Harper UL, Wincovitch SM, Wedel JC, Incao AA, Huebecker M, Boehm FJ, Garver WS, Porter FD, Broman KW, Platt FM, Pavan WJ: Genetic background modifies phenotypic severity and longevity in a mouse model of Niemann-Pick disease type C1. Dis Model Mech 2020, 13:dmm042614

64. Cougnoux A, Drummond RA, Collar AL, Iben JR, Salman A, Westgarth H, Wassif CA, Cawley NX, Farhat NY, Ozato K, Lionakis MS, Porter FD: Microglia activation in Niemann-Pick disease, type $\mathrm{C} 1$ is amendable to therapeutic intervention. Hum Mol Genet 2018, 27:2076-2089

65. Kim JY, Jang MK, Lee SS, Choi MS, Bok SH, Oh GT, Park YB: Rab7 gene is up-regulated by cholesterol-rich diet in the liver and artery. Biochem Biophys Res Commun 2002, 293:375-382

66. Schulze RJ, Rasineni K, Weller SG, Schott MB, Schroeder B, Casey CA, McNiven MA: Ethanol exposure inhibits hepatocyte lipophagy by inactivating the small guanosine triphosphatase Rab7. Hepatol Commun 2017, 1:140-152

67. Torres S, Matias N, Baulies A, Nunez S, Alarcon-Vila C, Martinez L, Nuno N, Fernandez A, Caballeria J, Levade T,
Gonzalez-Franquesa A, Garcia-Roves P, Balboa E, Zanlungo S, Fabrias G, Casas J, Enrich C, Garcia-Ruiz C, Fernandez-Checa JC: Mitochondrial GSH replenishment as a potential therapeutic approach for Niemann Pick type C disease. Redox Biol 2017, 11: $60-72$

68. Charman M, Kennedy BE, Osborne N, Karten B: MLN64 mediates egress of cholesterol from endosomes to mitochondria in the absence of functional Niemann-Pick Type C1 protein. J Lipid Res 2010, 51: $1023-1034$

69. Klein $\mathrm{AD}$, Gonzalez de la Vega J, Zanlungo S: Complement component C3 participates in early stages of Niemann-Pick C mouse liver damage. Int J Mol Sci 2020, 21:2127

70. Magro Dos Reis I, Houben T, Oligschlager Y, Bucken L, Steinbusch H, Cassiman D, Lutjohann D, Westerterp M, Prickaerts J, Plat J, Shiri-Sverdlov R: Dietary plant stanol ester supplementation reduces peripheral symptoms in a mouse model of Niemann-Pick type C1 disease. J Lipid Res 2020, 61:830-839

71. Vincent M, Sayre NL, Graham MJ, Crooke RM, Shealy DJ, Liscum L: Evaluation of an anti-tumor necrosis factor therapeutic in a mouse model of Niemann-Pick C liver disease. PLoS One 2010, 5: e12941

72. Calderon JF, Klein AD: Controversies on the potential therapeutic use of rapamycin for treating a lysosomal cholesterol storage disease. Mol Genet Metab Rep 2018, 15:135-136

73. Guillot A, Tacke F: Liver macrophages: old dogmas and new insights. Hepatol Commun 2019, 3:730-743

74. Lee H, Lee JK, Min WK, Bae JH, He X, Schuchman EH, Bae JS, Jin HK: Bone marrow-derived mesenchymal stem cells prevent the loss of Niemann-Pick type C mouse Purkinje neurons by correcting sphingolipid metabolism and increasing sphingosine-1-phosphate. Stem Cells 2010, 28:821-831

75. Zeng TS, Liu FM, Zhou J, Pan SX, Xia WF, Chen LL: Depletion of Kupffer cells attenuates systemic insulin resistance, inflammation and improves liver autophagy in high-fat diet fed mice. Endocr J 2015, 62:615-626

76. Yang YY, Huang YT, Tsai TH, Hou MC, Lee FY, Lee SD, Lin HC: Kupffer cell depletion attenuates leptin-mediated methoxaminestimulated portal perfusion pressure and thromboxane A2 release in a rodent model of NASH-cirrhosis. Clin Sci (Lond) 2012, 123: 669-680

77. Chen Y, Liu Z, Liang S, Luan X, Long F, Chen J, Peng Y, Yan L, Gong J: Role of Kupffer cells in the induction of tolerance of orthotopic liver transplantation in rats. Liver Transpl 2008, 14: 823-836

78. Reverter M, Rentero C, de Muga SV, Alvarez-Guaita A, Mulay V, Cairns R, Wood P, Monastyrskaya K, Pol A, Tebar F, Blasi J, Grewal T, Enrich C: Cholesterol transport from late endosomes to the Golgi regulates t-SNARE trafficking, assembly, and function. Mol Biol Cell 2011, 22:4108-4123

79. Campbell KA, Minashima T, Zhang Y, Hadley S, Lee YJ, Giovinazzo J, Quirno M, Kirsch T: Annexin A6 interacts with p65 and stimulates NF-kappaB activity and catabolic events in articular chondrocytes. Arthritis Rheum 2013, 65: $3120-3129$ 